\title{
Surgical management of displaced midshaft clavicle fracture in skeletally immature patient- What is the evidence?
}

\author{
Saloumeh Saremi ${ }^{1}$ and Saeed Asadollahi ${ }^{2 *}$ \\ ${ }^{1}$ LaTrobe University, School of pharmacy and applied science \\ ${ }^{2}$ Westmead children hospital, Sydney, Australia
}

\begin{abstract}
Background: There has been a shift towards surgical management of displaced midshaft clavicle fractures in adults over last decade. There seems to be a change towards operative management of displaced midshaft clavicle fracture in skeletally immature patients, driven by published literature in adult clavicle fracture setting.

Methods: We performed a systematic review to evaluate the outcome and complications associated with surgical fixation of displaced midshaft clavicle fracture in children. Electronic searches of the PubMed, Embase and Cochrane library were performed. Studies were included if they reported the outcome of operative fixation of displaced midshaft clavicle fracture in skeletally immature patient.

Results: Eight studies were included. All but one study were retrospective reviews. The total number of 138 patients were identified. Intramedullary fixation was performed in 54 (39\%), plate and screw in 82 (59\%) and external fixation in 2 cases (2\%). The overall incidence of complication was $8 \%$ ( $\mathrm{n}=11$ ). The overall non-union rate was $0.7 \%(n=1)$. Symptomatic implant requiring removal was seen in $41 \%$ of operated patients $(n=56)$.
\end{abstract}

Conclusion: Although indications for surgical management of displaced midshaft clavicle fractures are uncommon in skeletally immature patient, operative fixation of displaced midshaft clavicle fractures in selected cases seems to be safe and effective.

Level of evidence: IV

\section{Introduction}

The clavicle is the most commonly fractured bone in children which accounts for $10 \%-15 \%$ of all paediatric fractures [1]. Midshaft clavicle fractures are the most common, including $80 \%$ of fractures [1]. The annual incidence is about 25 fractures per 10,000 children younger than 19 years [2].

Recent evidence has shown operative fixation of displaced midshaft clavicle fracture is superior to non-operative management with higher union rate and improved functional outcome [3-5]. Consequently, there has been an increasing trend towards surgical fixation of clavicle fractures in adults $[3,6]$.

The changing approach favouring surgical management of displaced midshaft clavicle fractures has influenced the management of displaced midshaft clavicle fractures in children [2,7-9]. Although the principles of surgical treatment of clavicle fractures in adults may not be quite applicable to the paediatric population due to high healing and remodelling potentials $[1,5,10-12]$.

The current evidence on surgical management of paediatric clavicle fractures is limited [8,12-15]. The purpose of this study is to perform a systematic review of surgical treatment of displaced midshaft clavicle fracture in skeletally immature patients focusing on the outcome and complication profile of surgically treated fractures.

\section{Material and methods}

In July 2017, an electronic search using PubMed, Embase and Cochrane library was performed. The search terms used were as follows: "clavicle fracture", "midshaft", "displaced", "paediatric", "adolescent" and "complication". Studies were shortlisted for inclusion if they pertained to the surgical treatment of midshaft clavicle fracture in skeletally immature patient. Case reports and studies with no reported outcome were excluded. The abstracts of the short listed studies were then reviewed and selected abstracts were considered for the full text review. Reference sections of all accessed papers were searched for any undetected studies. English language restriction was applied. If studies presented data on acute midshaft fractures mixed with lateral or medial, the results for acute midshaft fractures were extracted. Complication is defined as any adverse event requiring further treatment [1].

\section{Result}

We identified nine studies on surgical treatment of displaced midshaft clavicle fractures. One of the studies was excluded as it didn't report the outcome of surgical fixation [8]. Table 1 shows the details

Correspondence to: Saeed Asadollahi MD, FRACS, Orthopaedic Registrar Westmead Children Hospital, Sydney, Australia, Tel: +6129845000; E-mail: saeedasadollahi@yahoo.com

Received: June 08, 2017; Accepted: July 19, 2017; Published: July 21, 2017 
Table 1. Details of included studies on surgical management of midshaft clavicle fracture in skeletally immature patient

\begin{tabular}{|c|c|c|c|c|c|c|c|}
\hline Year & Author & No. of fractures & Age (range) & Plate & IM device $\dagger$ & $\begin{array}{c}\text { Complication } \\
\text { (excluding symptomatic implant) }\end{array}$ & Union \\
\hline 2015 & Luo et al & 23 & $14-17$ & 19 & 4 & $22 \%$ & $96 \%$ \\
\hline 2014 & Randsborg et al & 9 & $10-18$ & 9 & - & - & $100 \%$ \\
\hline 2013 & Rapp et al & 25 & $10-15$ & - & 25 & $20 \%$ & $100 \%$ \\
\hline 2012 & Frye et al & 17 & $13-18$ & 0 & 17 & $18 \%$ & $100 \%$ \\
\hline 2011 & Namdari et al & 14 & $10-15$ & 14 & 0 & - & $100 \%$ \\
\hline 2010 & Vander Have et al & 18 & $12-17$ & 18 & 0 & - & $100 \%$ \\
\hline 2009 & Mehlman et al & 24 & $7-16$ & 22 & 2 & $8 \%$ & $100 \%$ \\
\hline 2002 & Kubiak and Slongo & 8 & $9-15$ & 0 & $6^{*}$ & - & $100 \%$ \\
\hline
\end{tabular}

$\dagger$ Intramedullary device

* 2 other remaining fractures were stabilised with external fixation

of the included studies $[1,11,12,14-18]$. All but one study [16] were retrospective series. The study by Vander Have et al is the only study with nonoperative control group [14].

A total of 138 fractures were identified. Most of the fractures occurred in boys (78\%). Intramedullary fixation was performed in 54 (39\%), plate fixation in $82(59 \%)$, and external fixation in 2 cases $(2 \%)$. Overall, the nonunion rate was $0.7 \%$.

Table 2 shows the complication profile of the open reduction internal fixation of clavicle fracture in the included series. The overall complication rate is $8 \%$. Symptomatic implant requiring removal occurred in $41 \%$ of patients $(n=56)$. Numbness and reduced skin sensation around the scar and dissatisfaction from surgical scars aren't included in the complication table despite being reported by some of the included studies. We believe these post-operative findings aren't uncommon and are usually under-reported in published series.

\section{Discussion}

Controversy exists on the indications for operative management of midshaft clavicle fractures in children and a wide variation in practice exists [1,7]. The current indications for surgical management of midshaft clavicle fractures in adult patients include [3]: completely displaced midshaft fracture with shortening of $>2 \mathrm{~cm}$, skin tenting, associated neuro-vascular injury, open clavicular fracture; and floating shoulder with a completely displaced clavicular fracture.

However, applying the above mentioned indications into paediatric setting is not straightforward. For example, one of the arguments for operative management of displaced midshaft fracture in adults is high rate of symptomatic malunion [10]. Whereas, clavicle fracture malunion can potentially remodel in younger children [19], and generally a small percentage of clavicle fracture malunions become symptomatic in this age group [10]. Another example is justifying operative management of clavicle fractures in adults to reduce the non-union rate, whilst as shown in this review the non-union rate in paediatric clavicle facture is $<1 \%$ following nonoperative management.

This systematic review shows that the complication rate associated with operative treatment of displaced midshaft clavicle fracture can occur up to $8 \%$ of operated cases. In the only case control study by Vander Have et al symptomatic malunion rate of $20 \%$ can occur following nonoperative treatment of displaced shortened midshaft clavicle fracture in adolescents [14]. Furthermore, the authors showed operative fixation of displaced midshaft clavicle fracture results in earlier union and return to activities [14].

The current literature of surgical treatment of displaced midshaft clavicle fracture has multiple shortcomings. Most of reports are
Table 2. Complication profile

\begin{tabular}{|l|c|}
\hline \multicolumn{1}{|c|}{ Complication } & Number \\
\hline Implant breakage & 3 \\
\hline Refracture & 2 \\
\hline Hypersensitive scar & 2 \\
\hline Implant bending requiring exchange & 2 \\
\hline Nonunion and implant failure & 1 \\
\hline Superficial wound dehiscence & 1 \\
\hline
\end{tabular}

retrospective case series with inherent limitations of a retrospective study design. Most of the available studies have short to midterm follow ups and lack subjective and/or functional outcome.

While nonoperative treatment remains the mainstay of management in majority of children with midshaft clavicle fracture, open reduction and internal fixation of displaced clavicle shaft fractures in selected children can be performed safely. Randomised controlled trials will need to be performed in order to compare the outcome of treatment of nonoperative versus operative treatment of displaced midshaft clavicle fractures in paediatric population.

\section{References}

1. Luo TD, Ashraf A, Larson AN, Stans AA, Shaughnessy WJ, et al. (2015) Complications in the treatment of adolescent clavicle fractures. Orthopedics 38: e287-291. [Crossref]

2. Heyworth BE, Suppan CA, Kocher MS (2014) Change in the volume of operative treatment of clavicle fractures in children and adolescents: National trends and practice patterns, AOSSM 2014, Seattle, OR.

3. Canadian Orthopaedic Trauma Society (2007) Nonoperative treatment compared with plate fixation of displaced midshaft clavicular fractures. Multicenter, randomized clinical trial. J Bone Joint Surg Am 89: 1-10. [Crossref]

4. McKee MD, Pedersen EM, Jones C, Stephen DJ, Kreder HJ, et al. (2006) Deficits following nonoperative treatment of displaced midshaft clavicular fractures. J Bone Joint Surg Am 88: 35-40. [Crossref]

5. Hill JM, McGuire MH, Crosby LA (1997) Closed treatment of displaced middle-third fractures of the clavicle gives poor results. J Bone Joint Surg Br 79: 537-539. [Crossref]

6. Smekal V, Irenberger A, Struve P, Wambacher M, Krappinger D, et al. (2009) Elastic stable intramedullary nailing versus nonoperative treatment of displaced midshaft clavicular fractures-a randomized, controlled, clinical trial. J Orthop Trauma 23: 106112. [Crossref]

7. Carry PM, Koonce R, Pan Z, Polousky JD (2011) A survey of physician opinion adolescent midshaft clavicle fracture treatment preferences among POSNA members. $J$ Pediatr Orthop 31: 44-49. [Crossref]

8. Suppan CA, Bae DS, Donohue KS, Miller PE, Kocher MS, et al. (2016) Trends in the volume of operative treatment of midshaft clavicle fractures in children and adolescents: a retrospective, 12-year, single-institution analysis. J Pediatr Orthop B 25: 305-309. [Crossref]

9. Yang S, Werner BC, Gwathmey FW Jr (2015) Treatment trends in adolescent clavicle fractures. J Pediatr Orthop 35: 229-233. [Crossref] 
10. McIntosh AL (2016) Surgical Treatment of Adolescent Clavicle Fractures: Results and Complications. J Pediatr Orthop 36 Suppl 1: S41-43. [Crossref]

11. Randsborg PH, Fuglesang HF, Røtterud JH, Hammer OL, Sivertsen EA (2014) Longterm patient-reported outcome after fractures of the clavicle in patients aged 10 to 18 years. J Pediatr Orthop. 34: 393-399. [Crossref]

12. Kubiak R, Slongo T (2002) Operative treatment of clavicle fractures in children: a review of 21 years. $J$ Pediatr Orthop 22: 736-739. [Crossref]

13. Schulz J, Moor M, Roocroft J, Bastrom TP, Pennock AT (2013) Functional and radiographic outcomes of nonoperative treatment of displaced adolescent clavicle fractures. J Bone Joint Surg Am 95: 1159-1165. [Crossref]

14. Vander Have KL, Perdue AM, Caird MS, Farley FA (2010) Operative versus nonoperative treatment of midshaft clavicle fractures in adolescents. J Pediatr Orthop 30: 307-312. [Crossref]
15. Mehlman CT, Yihua G, Bochang C, Zhigang W (2009) Operative treatment of completely displaced clavicle shaft fractures in children. J Pediatr Orthop 29: 851-855. [Crossref]

16. Rapp M, Prinz K, Kaiser MM (2013) Elastic stable intramedullary nailing for displaced pediatric clavicle midshaft fractures: a prospective study of the results and patient satisfaction in 24 children and adolescents aged 10 to 15 years. J Pediatr Orthop 33: 608-613. [Crossref]

17. Namdari S, Ganley TJ, Baldwin K, Rendon Sampson N, Hosalkar H, et al. (2011) Fixation of displaced midshaft clavicle fractures in skeletally immature patients. $J$ Pediatr Orthop 31: 507-511. [crossref]

18. Frye BM, Rye S, McDonough EB, Bal GK (2012) Operative treatment of adolescent clavicle fractures with an intramedullary clavicle pin. J Pediatr Orthop 32: 334-339. [Crossref]

19. McGraw MA, Mehlman CT, Lindsell CJ, Kirby CL (2009) Postnatal growth of the clavicle: birth to 18 years of age. J Pediatr Orthop 29: 937-943. [Crossref]

Copyright: $\odot 2017$ Saremi S. This is an open-access article distributed under the terms of the Creative Commons Attribution License, which permits unrestricted use, distribution, and reproduction in any medium, provided the original author and source are credited. 